\title{
Factors and Common Conditions Associated with Consumption of Nutritional Supplements among Adolescents in Makkah, Saudi Arabia
}

\author{
Reham A. Moustafa* \\ Clinical Nutrition Department, Faculty of Applied Medical Sciences, \\ Umm AlQura University, Makkah, Saudi Arabia \\ *Corresponding author
}

A B S T R A C T

\begin{abstract}
\begin{tabular}{|c|}
\hline Keywords \\
\hline $\begin{array}{l}\text { Dietary supplements, } \\
\text { Adolescences, } \\
\text { Consumption, } \\
\text { Knowledge }\end{array}$ \\
\hline Article Info \\
\hline $\begin{array}{l}\text { Accepted: } \\
12 \text { March } 2018 \\
\text { Available Online: } \\
10 \text { April } 2018\end{array}$ \\
\hline
\end{tabular}
In the last decades, dietary supplements consumption has increased in the Western world for all age groups. The long-term potentially dangerous effects related to an indiscriminate consumption of dietary supplements are still unknown and are becoming a matter of public health concern. Therefore, the aims of the present study were to explore the contribution of dietary supplements intake, and to evaluate awareness and knowledge about dietary supplements. 196 Participants (age ranging from 11 to 19 years) were recruited among students attending primary, intermediate, secondary schools and university in Makkah. An structured questionnaire, composed of 9 multiple-choice items, was administered to all the participants. The analysis of variance (ANOVA) was performed to describe differences between means of the groups, while the chi-square test was used to compare observed and expected frequencies. The results showed a significant differences $(<0.05)$ between education level of the participants and their knowledge about the dietary supplement, The reason for using food supplement between male and female showed significant differences. This study has indicated the prevalence of dietary supplements usage, increasing the knowledge about dietary supplements and different reasons for the using food supplements.
\end{abstract}

\section{Introduction}

The dietary supplement industry is now a multi-billion dollar industry, there is growing pressure, and a subsequent need for research to establish the efficacy and safety of these products particularly for adolescent users. The psychological and educational components of such use cannot be ignored as they play an equally important role in the health and safety of adolescents (Kim and Ali, 2005). Medical evidence has suggested that dietary supplementation may be beneficial for a small group of people, including competitive athletes, who do not have balanced diet (Scofield and Unruh, 2006).

In such cases, after nutritional deficiency has been detected, the increase in the intake of such nutrients is recommended, either by means of food or supplements.

However, there has been an increasing use of supplements by adolescents engaged in physical or athletic activities (Calfee and Fadale, 2006). 
Consumption prevalence varies according to types of sports (it is often used for weight lifting and bodybuilding), cultural aspects, age groups (more common among adolescents) and sex (higher prevalence among men) (Maughan et al., 2004 and Pereira et al., 2003).

Few studies have mentioned the frequency, type and amount of supplements used, but it seems that the recommended doses are often exceeded.

Unfortunately, most of the time, this consumption does not have the necessary guidance, and it is a result of suggestions from classmates, coaches, magazine websites, and conversations with people who attend gyms (Burns et al., 2004 and Petróczi et al., 2007). Furthermore, these products are sold in drugstores or gyms as over-the-counter products without advice from a nutritionist (Calfee and Fadale, 2006; Petróczi et al., 2007 and Carvalho, 2003).

\section{Materials and Methods}

\section{Participant and sampling}

Across sectional study was carried out during the period from (10/11/13/1435AH) to(1/2/1436AH) among a random sample of (196) adolescents female (123) and male (73) students from Makkah Almokarama aged between (11-19 years) from different level of education; primary school (2 from female), intermediate school (44 from female, 15 from male), secondary school (45 from female, 40 from male) and university (32 from female, 18 from male).

\section{Data collection}

Data was collected through a structured questionnaire compose of three sections: (Appendix).
Section A: Demographic data.

Section B: Anthropometric measurements.

Section C: Consumption of food supplements.

\section{Anthropometric measurements}

Assessment of study outcomes includes anthropometric measurements:

Height was measured by using inelastic measuring tape, the person stood steady without shoes. Weight was assessed by using electronic army (ISO 9001: 2000 certified by SCS model: EB9010 scale). The person stands in the center of the scale without shoes and with minimum clothing (Robert and David 2006).

BMI was calculated by dividing weight (in kilogram)/height (in meter) ${ }^{2}$, the grades of body mass index were classified according to Quetelet's index (QI) by (Garrow, 1988).

\section{Consumption of food supplements}

In this section ask the volunteers if they know about food supplements, if they uses, what type they use and what is the reasons for using it.

\section{Statistical analysis}

Statistical analysis has been achieved using IMB-P-C computer by SPSS v16 program (SPSS, 2008), and compared with each other using the suitable tests. All obtained results were tabulated.

\section{Results and Discussion}

Regarding to the table 1 the frequency distribution for male and female subjects found from the total members of samples that 196 members $73(37.2 \%)$ of them from male and the remaining $123(62.8 \%)$ is form the female, as shown in figure 1. 
The educations level of subjects showing in table 1 found that significant differences between the male and female (.041) calculated 2 from primary school, 59 from intermediate school, 58 from secondary school and 50 from university as showing in figure 2 .

Regarding to anthropometric measurement as shown in table 2 found that highly significant differences between the male and female (.000) as shown in weight $(58.0915 \pm 17.96)$ and $(50.96 \pm 11.15)$ respectively and found also highly significant differences between the male and female (.000) as shown in height $(163.2 \pm 14.172)(156.43 \pm 7.09)$ respectively.

Finally, found also highly significant differences between the male and female (.004) as shown in BMI (21.83 \pm 6.049$)$ $(20.8 \pm 4.67)$ respectively as shown in figure 3 .

Regarding to the result the figure 4 showed the frequency distribution of male and female subjects according to their knowledge and using supplements found significant differentiation(.010) between males and females in the using the food supplements regarding to table 3 . From our study observes that 22 subject from male did not know the food supplement while it was 46 subject from male use food supplement and 28 subject from female did not know the food supplement while it was 54 subject use food supplement.

The result in table 3 showed no significant differentiation between male and female in the type of food supplement the use (.165) as shown in figure 5.

There were higher significant differentiation between male and female in the reason for using food supplement (0.00), found that 11 subjects of the male are using dietary supplements for hair improvement with 24 subjects of the female group, and found that 24 subjects of the male are using dietary supplements for increase muscles mass with 1 subjects of the female group.

The table 4 shows the number of students who use dietary supplements were 100 students, a small group of them (14 students) were using supplements and did not know about the supplement.

The total of Students who did not use dietary supplements was 96 students 36 of them do not know dietary supplements and do not use it (Fig. 6 and 7).

It was found that significant differences between the educational level and the knowledge about the food supplement (.013). While the secondary school recorded the highest value of knowledge 63 student from 146 student; and intermediate school was 40 student and university was 43 student and found that 50 student from various educational level where did not know any think about food supplement as show in figure 8 .

Also in our result found highly significant differences between the using of supplement and the educational level (.000) as show in figure 8 . While 61 students from secondary school answer yes from total 100 most of them from secondary school level (61 students). Also noticed through our study that the type of food supplement use and reasons for using it did not show significant different as shown in figure 9 and 10 respectively.

Studies have indicated the prevalence of dietary supplement usage by adolescents range from approximately $10 \%$ to as high as $74 \%$. Some of the highest rates of usage appear in chronically ill adolescents. Multivitamin and mineral preparations are the most common supplements being consumed; however, many studies indicate that adolescents are using other substances like creatine, herbals, or protein supplements. 
Table.1 Frequency distribution of male and female subjects according to their demographic data

\begin{tabular}{|c|c|c|c|c|c|c|}
\hline \multirow[t]{3}{*}{ Variables } & \multicolumn{2}{|c|}{$\operatorname{male}(n=196)$} & \multicolumn{2}{|c|}{ female $(n=196)$} & \multirow{2}{*}{$\begin{array}{c}\text { Chi - } \\
\text { Square }\end{array}$} & \multirow[t]{2}{*}{ P-value } \\
\hline & No & $\%$ & No & $\%$ & & \\
\hline & 73 & 37.2 & 123 & 62.8 & & \\
\hline \multicolumn{7}{|l|}{ Education level } \\
\hline Illiterate & 0 & 0 & 0 & 0 & \multirow[t]{5}{*}{.041} & \multirow[t]{5}{*}{8.250} \\
\hline Primary school & 0 & 0 & 2 & $1.626 \%$ & & \\
\hline Intermediate school & 15 & $20.548 \%$ & 44 & $35.77 \%$ & & \\
\hline Secondary school & 40 & $54.79 \%$ & 45 & $36.59 \%$ & & \\
\hline University & 18 & $24.66 \%$ & 32 & $26.02 \%$ & & \\
\hline Total & 73 & $100 \%$ & 123 & $100 \%$ & & \\
\hline
\end{tabular}

Table.2 Mean \pm SD values of BMI for the subjects according to their weight and height

\begin{tabular}{|c|c|c|c|c|}
\hline \multirow{2}{*}{ Factors } & Male & Female & F & P \\
& M \pm SD & M \pm SD & & \\
\hline Weight $(\mathrm{Kg})$ & $58.0915 \pm 17.96$ & $50.96 \pm 11.15$ & 38.26 & .000 \\
\hline Height $(\mathrm{cm})$ & $163.2 \pm 14.172$ & $156.43 \pm 7.09$ & 25.64 & .000 \\
\hline BMII $\left(\mathrm{Kg} / \mathrm{cm}^{2}\right)$ & $21.83 \pm 6.049$ & $20.8 \pm 4.67$ & 8.74 & .004 \\
\hline
\end{tabular}

Table.3 Frequency distribution of male and female subjects according to consumption of food Supplements

\begin{tabular}{|c|c|c|c|c|c|c|c|}
\hline \multirow[t]{2}{*}{ Questions } & \multirow[t]{2}{*}{ Answer No. } & \multicolumn{2}{|c|}{ Male $(n=73)$} & \multicolumn{2}{|c|}{ Female $(n=123)$} & \multirow{2}{*}{$\begin{array}{l}\text { Chi - } \\
\text { square }\end{array}$} & \multirow{2}{*}{$\begin{array}{c}\mathbf{P}- \\
\text { value }\end{array}$} \\
\hline & & No & $\%$ & No & $\%$ & & \\
\hline \multirow{2}{*}{$\begin{array}{l}\text { Do you know about } \\
\text { food Supplements }\end{array}$} & Yes & 51 & 69.86 & 95 & 77.23 & \multirow[t]{2}{*}{.252} & \multirow[t]{2}{*}{1.310} \\
\hline & No & 22 & 30.13 & 28 & 22.76 & & \\
\hline \multirow{2}{*}{$\begin{array}{l}\text { Do you use any food } \\
\text { Supplements }\end{array}$} & Yes & 46 & 63.01 & 54 & 43.9 & \multirow[t]{2}{*}{.010} & \multirow[t]{2}{*}{6.69} \\
\hline & No & 27 & 36.98 & 69 & 56.09 & & \\
\hline \multirow{5}{*}{$\begin{array}{l}\text { Type of food } \\
\text { supplements that } \\
\text { you use }\end{array}$} & Vitamins & 7 & 9.58 & 8 & 6.51 & \multirow[t]{5}{*}{.165} & \multirow[t]{5}{*}{6.50} \\
\hline & Minerals & 17 & 23.28 & 32 & 26.02 & & \\
\hline & Herbal & 6 & 8.22 & 6 & 4.88 & & \\
\hline & Proteins & 10 & 13.69 & 4 & 3.25 & & \\
\hline & Appetizers & 6 & 8.22 & 4 & 3.25 & & \\
\hline \multirow{6}{*}{$\begin{array}{l}\text { Reasons for using } \\
\text { food supplements }\end{array}$} & Hair, skin \& nails & 11 & 15.07 & 24 & 19.51 & \multirow[t]{6}{*}{.000} & \multirow[t]{6}{*}{39.46} \\
\hline & Weight lose & 2 & 2.74 & 13 & 10.57 & & \\
\hline & Weight gain & 6 & 8.22 & 10 & 8.13 & & \\
\hline & Bone \& teeth & 1 & 1.37 & 3 & 2.44 & & \\
\hline & $\begin{array}{l}\text { Increase muscle } \\
\text { mass }\end{array}$ & 24 & 32.88 & 1 & 0.81 & & \\
\hline & Anemia & 2 & 2.74 & 3 & 2.44 & & \\
\hline
\end{tabular}


Table.4 Association between knowledge and using supplements between subjects

\begin{tabular}{|c|c|c|c|c|}
\hline A wareness & Using supplements & $\begin{array}{c}\text { Did not Use } \\
\text { supplements }\end{array}$ & $\begin{array}{c}\text { Chi - } \\
\text { square }\end{array}$ & P - value \\
\hline $\begin{array}{c}\text { Know } \\
\text { supplement }\end{array}$ & 87 & 59 & .000 & 16.048 \\
\hline $\begin{array}{c}\text { Did not } \\
\text { know } \\
\text { supplement }\end{array}$ & 14 & 36 & \\
\hline Total & 101 & 95 & \\
\hline
\end{tabular}

Table.5 Association between consumption of food supplements and educational level of the subjects

\begin{tabular}{|c|c|c|c|c|c|c|c|}
\hline \multirow[t]{2}{*}{ Questions } & \multirow{2}{*}{$\begin{array}{l}\text { Answer } \\
\text { No. }\end{array}$} & \multicolumn{4}{|c|}{ Educational status (\%) for the subjects } & \multirow[t]{2}{*}{ total } & \multirow{2}{*}{$\begin{array}{l}\text { Chi - } \\
\text { Squar } \\
\text { e }\end{array}$} \\
\hline & & $\begin{array}{c}\text { Primary } \\
\text { school }\end{array}$ & $\begin{array}{c}\text { Intermediate } \\
\text { school }\end{array}$ & $\begin{array}{c}\text { Secondary } \\
\text { school }\end{array}$ & University & & \\
\hline \multirow{2}{*}{$\begin{array}{l}\text { Do you know } \\
\text { about food } \\
\text { Supplements }\end{array}$} & Yes & 0 & 40 & 63 & 43 & 146 & \multirow[t]{2}{*}{.013} \\
\hline & No & 2 & 19 & 22 & 7 & 50 & \\
\hline \multirow{2}{*}{$\begin{array}{l}\text { Do you use any } \\
\text { food } \\
\text { Supplements }\end{array}$} & Yes & 0 & 21 & 61 & 18 & 100 & \multirow[t]{2}{*}{.000} \\
\hline & No & 2 & 38 & 24 & 32 & 96 & \\
\hline \multirow{5}{*}{$\begin{array}{l}\text { Type of food } \\
\text { supplements } \\
\text { that you use }\end{array}$} & Vitamins & & 1 & 11 & 3 & 15 & \multirow[t]{5}{*}{.111} \\
\hline & Minerals & & 12 & 31 & 6 & 49 & \\
\hline & Herbal & & 1 & 9 & 2 & 12 & \\
\hline & Proteins & & 2 & 6 & 6 & 14 & \\
\hline & Appetizers & & 4 & 5 & 1 & 10 & \\
\hline \multirow{6}{*}{$\begin{array}{l}\text { Reasons for } \\
\text { using food } \\
\text { supplements }\end{array}$} & $\begin{array}{l}\text { Hair, skin } \\
\& \text { nails }\end{array}$ & & 7 & 23 & 5 & 35 & \multirow[t]{6}{*}{.571} \\
\hline & $\begin{array}{l}\text { Weight } \\
\text { lose }\end{array}$ & & 5 & 7 & 3 & 15 & \\
\hline & $\begin{array}{l}\text { Weight } \\
\text { gain }\end{array}$ & & 5 & 7 & 4 & 16 & \\
\hline & $\begin{array}{c}\text { Bone \& } \\
\text { teeth }\end{array}$ & & 0 & 4 & 0 & 4 & \\
\hline & $\begin{array}{l}\text { Increase } \\
\text { muscle } \\
\text { mass }\end{array}$ & & 4 & 16 & 5 & 25 & \\
\hline & Anemia & & 0 & 4 & 1 & 5 & \\
\hline
\end{tabular}


Fig(1): Frequancy distribution of male and female subjects

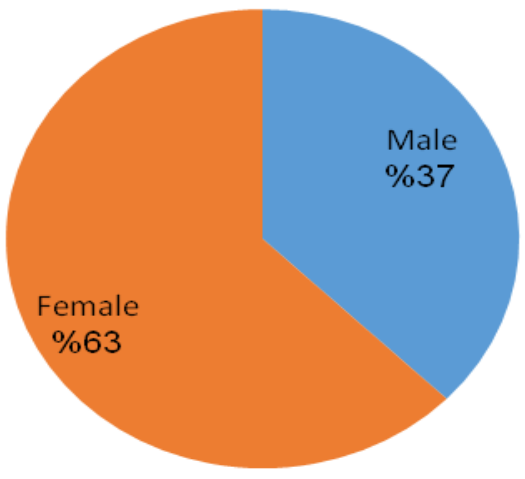

Fig.(2): Frequancy distribution of subjects according to educational level

Primary school

$\% 2$

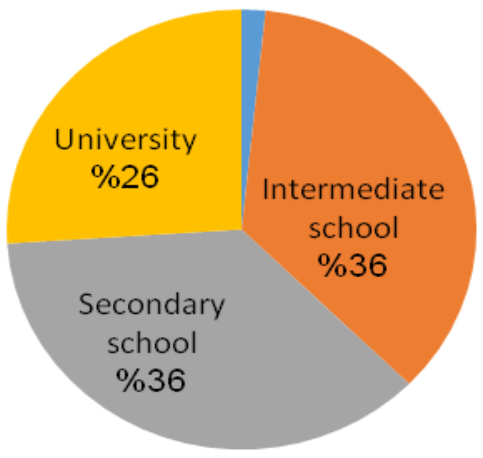

Fig.(3): Mean SD values of BMI for the subjects according to their weight \& height

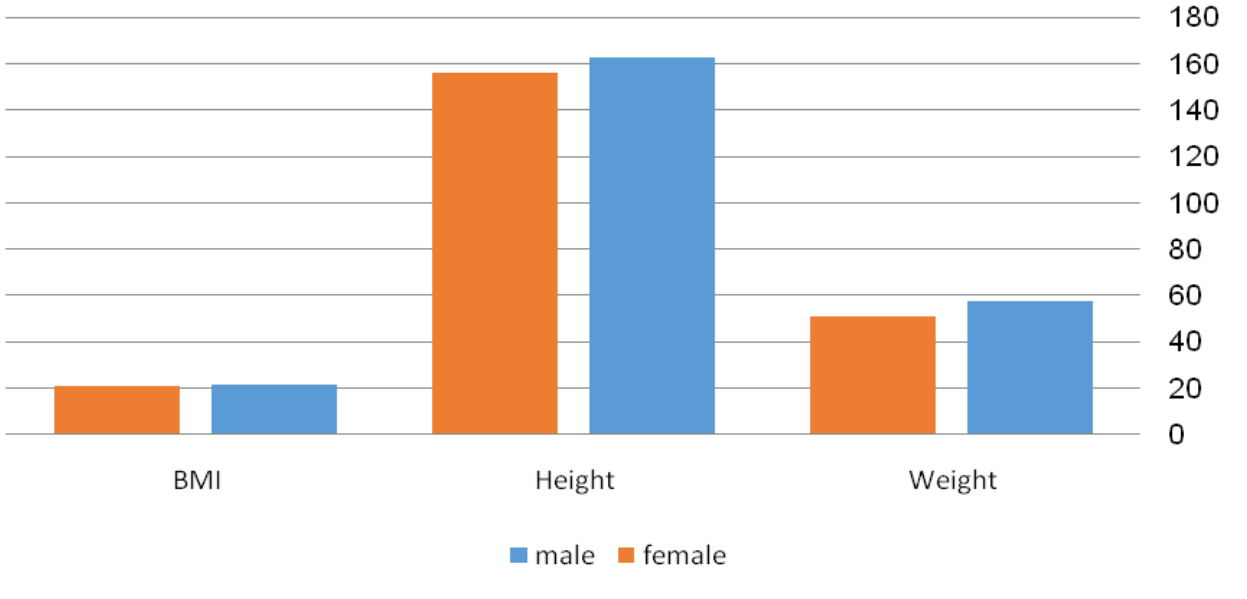



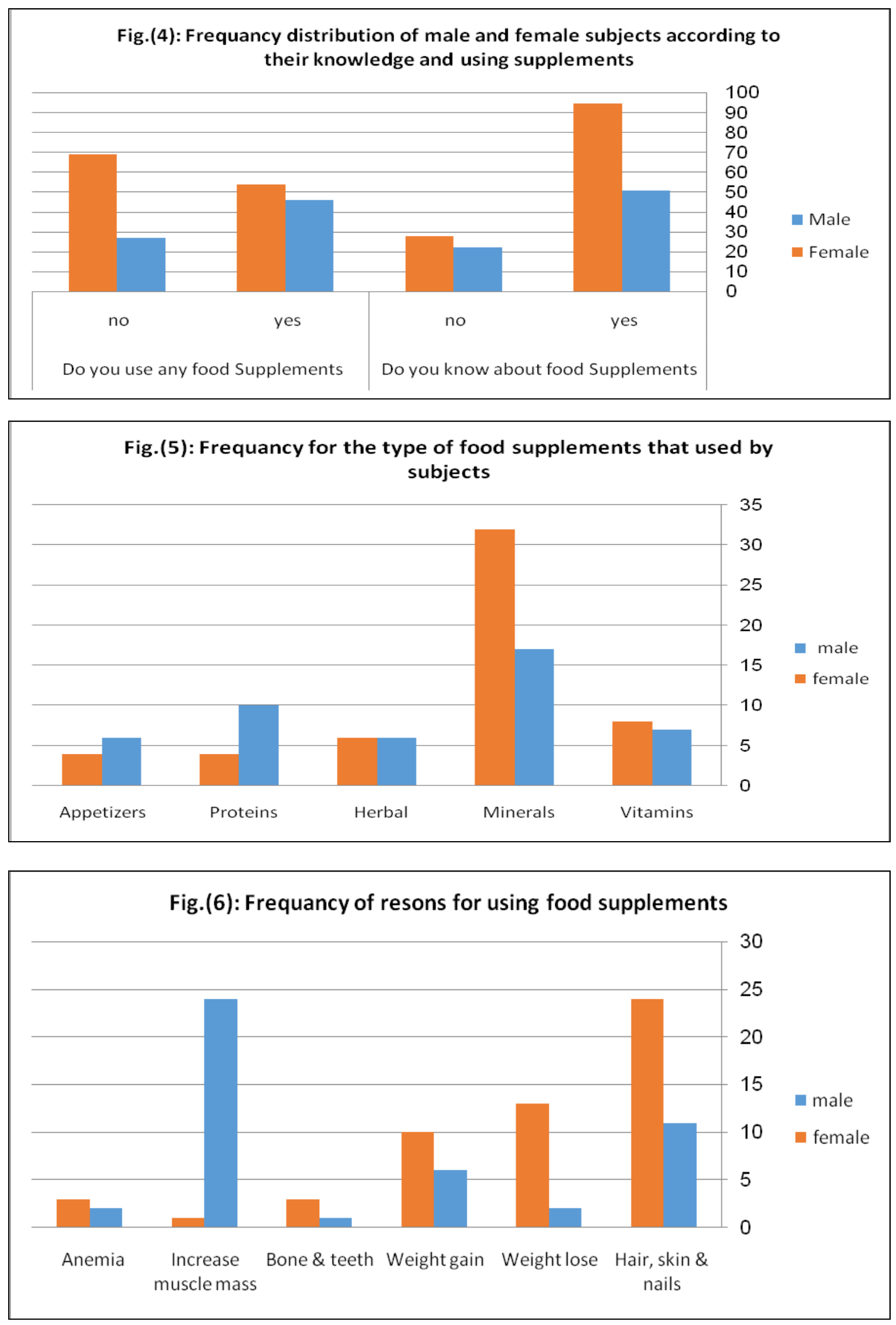
Fig.(7): Association between knowledge and using supplements between subjects

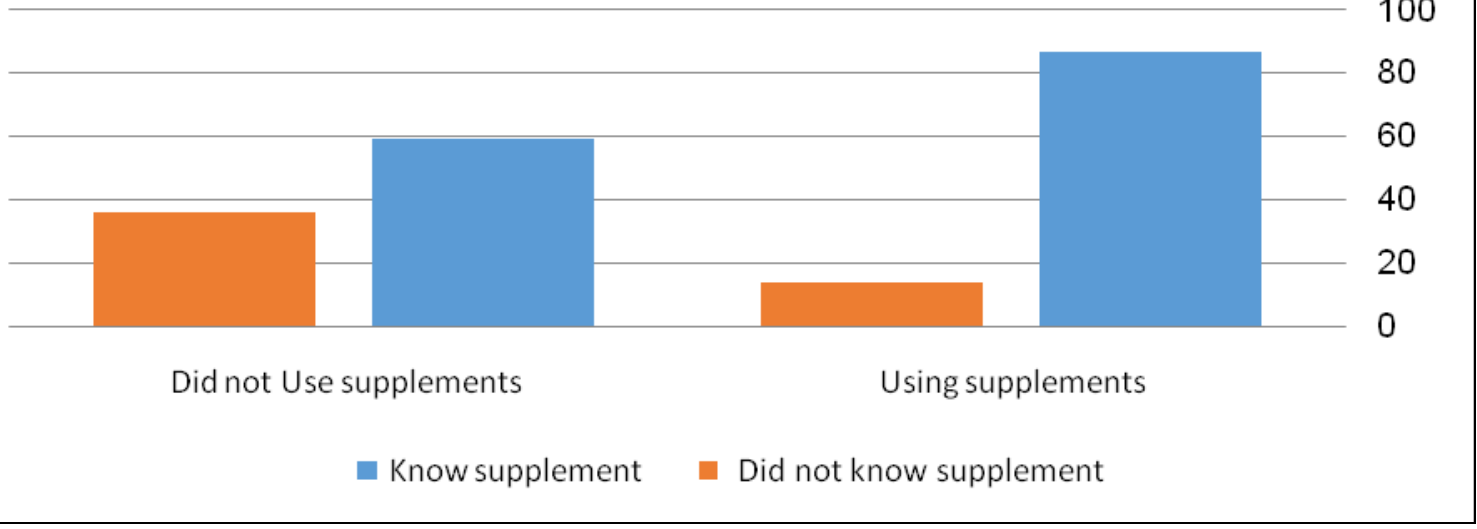

Fig.(8): Association between knowledge and the using of food supplements and educational level of the subjects

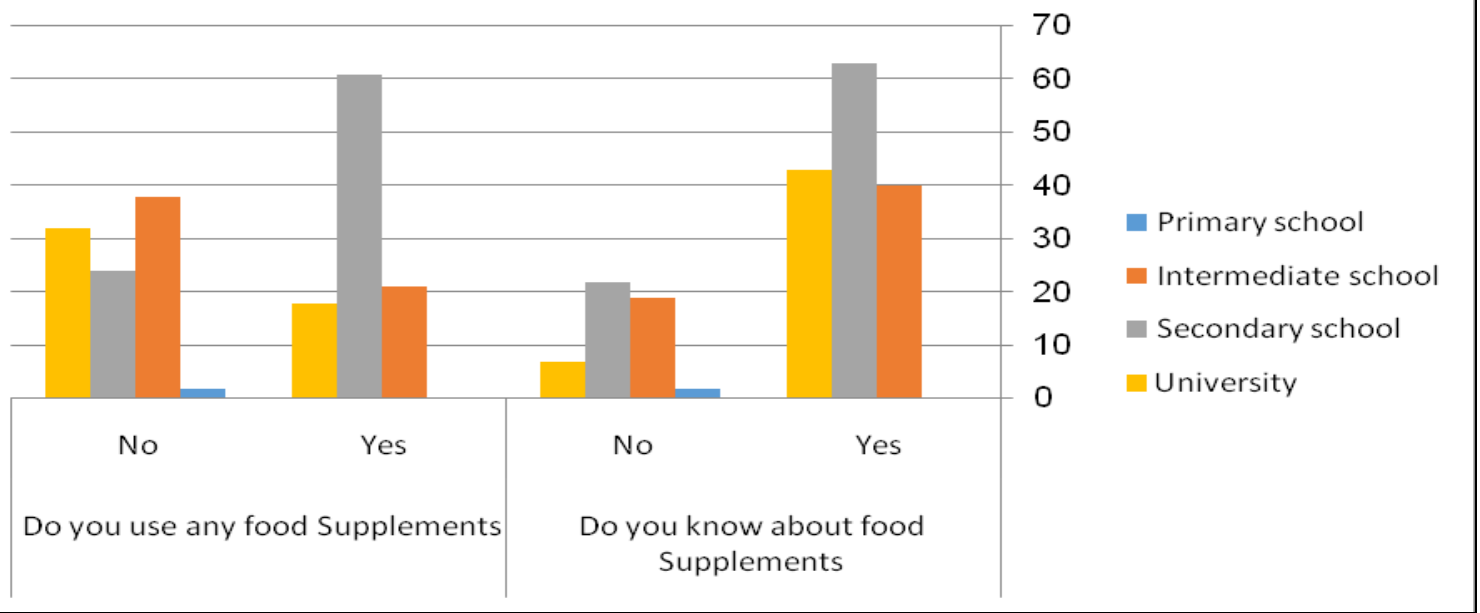

Fig.(9): Relationship between the type of food supplements and the educational level

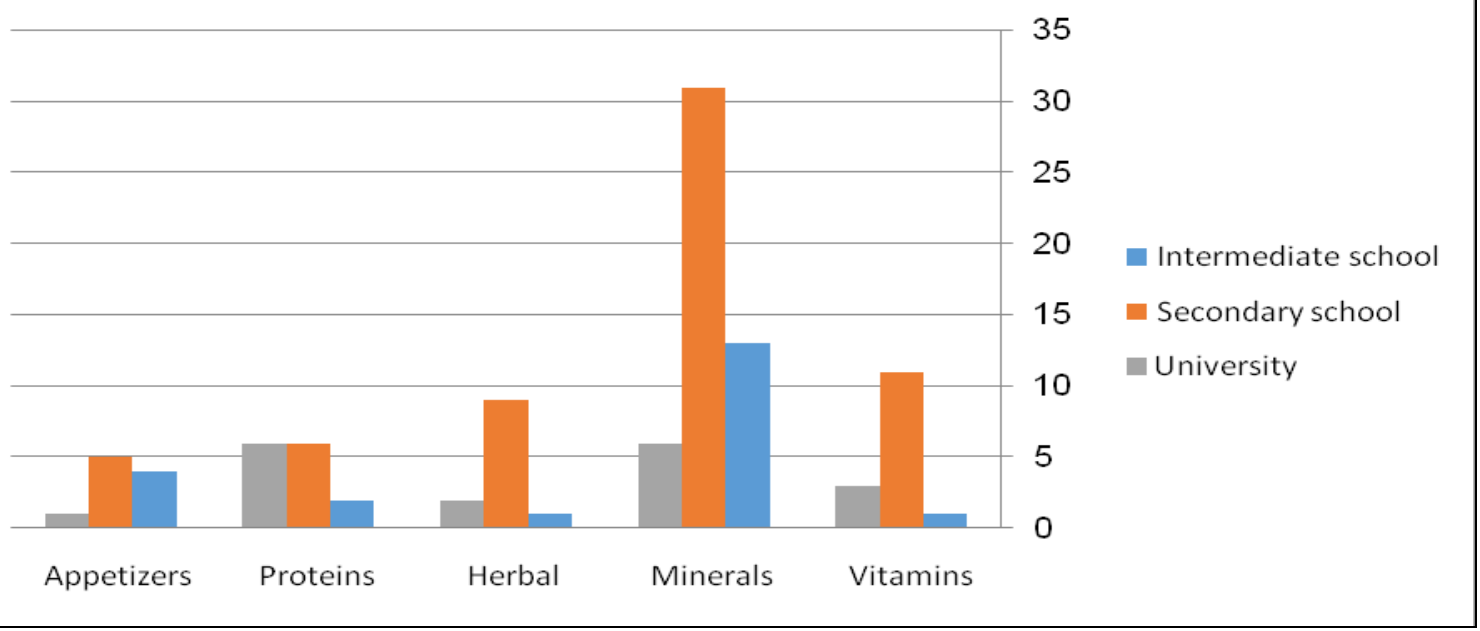




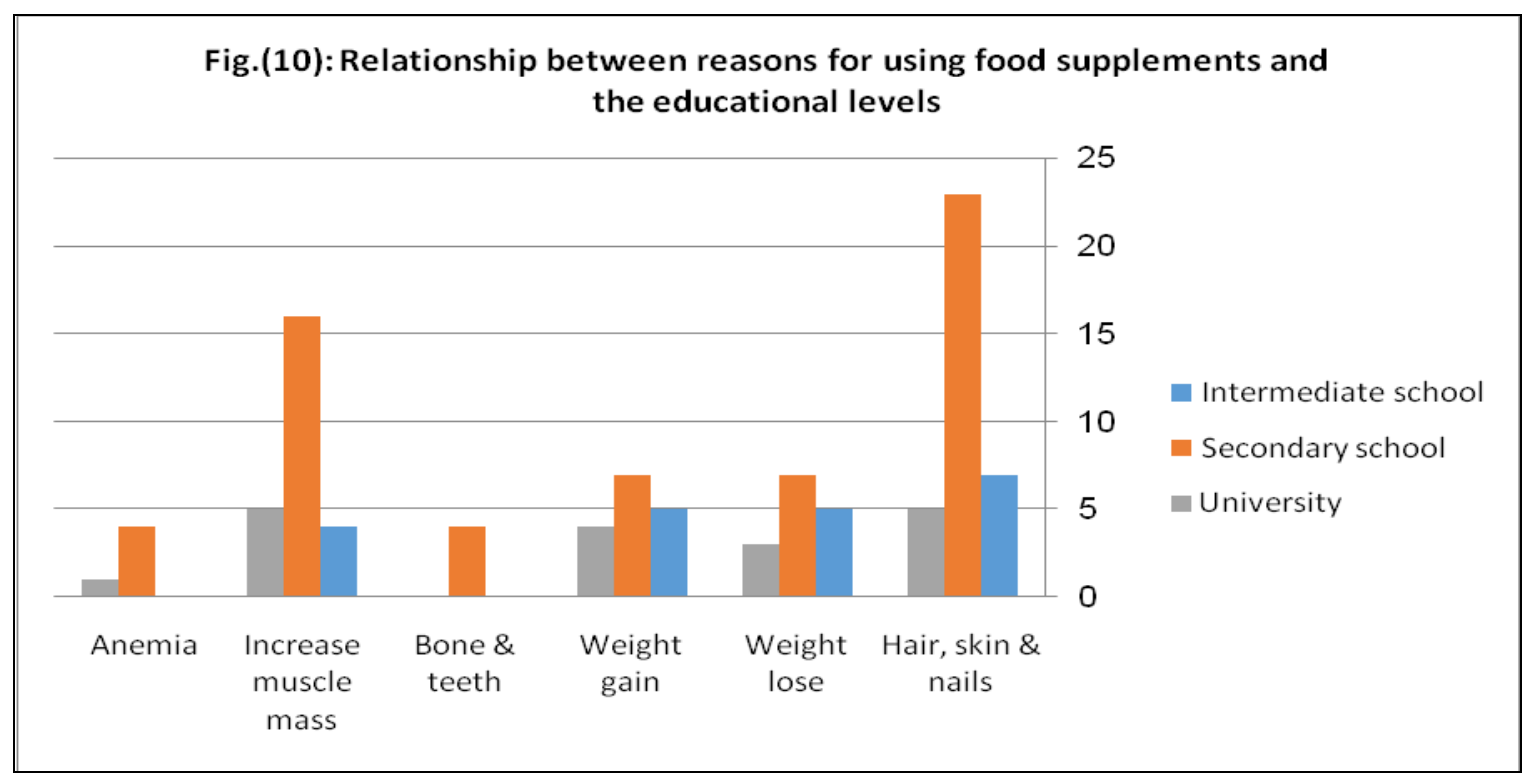

Some of the most appealing supplements among this age group are those that enhance athletic performance or physical appearance (Bell et al., 2004).

In this study describes the consumption of varieties of dietary supplement by adolescents in makkah, the total sample in our study were 196 person, including 123 women and 73 men studying in various stages of educational level.

Those with higher educational attainments were more likely to use dietary supplements, Dietary supplement use was different among all education levels, Picciano et al., (2007) reported that the highest use in those with more than a high school (HS) education (61\%) and lowest use in those with less than a HS education (37\%) (Bailey et al., 2011).

It was findthat 11 subjects of the male are using dietary supplements for hair, skin and nails compared with 24 subjects of the female group. Katarzyna Korzeniowska et al., (2014) found that the main reason for supplementation was the desire to improve the condition of the hair, reported both, women (59\%) and men (48\%) decided to supplement their diet mainly under the influence of the mass media: press, radio, TV and Internet. None of the women declared to follow the advice of a dietitian.
Media have played a significant role in shaping attitudes to numerous areas of life, including appearance or eating habits. Press, radio, TV and the Internet remain to be the main source of information, also about medicine-related topics, for many Polish people. Quite often, it is the content of an advertising message that significantly influences the decision whether or not to buy a given product be it a medicine or dietary supplement. For example, it was confirmed by Conner et al., (2001).

Over $50 \%$ of study participants identified the mass media as the stimulus behind the decision to use dietary supplements. In light of the fact that dietary supplements are commonly available outside a pharmacy, e.g. in the Internet stores, the process of educating consumers how to distinguish between medicinal products and supplements, or other products, is vital (Cellini et al., 2013).

A great number of people turn to the Internet in search of information on the effectiveness of dietary supplements. Alas, they are limited or scarce when it comes to the possibility of adverse effects.

Thus, it is essential to expand the knowledge of the consumers both on the positive and negative consequences of supplementation as well as to 
educate them about proper food-related behaviors (Liu, 2013). From our study observes the $30.13 \%$ subject from male did not know the food supplement while it was $63.01 \%$ subject from male use food supplement and $22.76 \%$ subject from female did not know the food supplement while it was $43.9 \%$ subject use food supplement. Katarzyna Korzeniowska et al., (2014) found that as far as the definition of a dietary supplement was concerned, 72 (63\%) of the respondents were not able to give a correct definition, whereas 37 (32\%) did not know it at all.

A vast majority of study participants (61\%) evaluated their own knowledge about dietary supplements as “average”. Women's knowledge appeared to be greater than men's this difference was statistically significant $(<0.05)$. The study of Bailey et al., (2006) and Kathy Radimer (2004) found that more types of dietary supplements commonly used among adolescents are the minerals and multivitamins also found the same results in this study. Where the total who have used minerals from all educational levels are 49 students and the total who are used vitamin 15 student.

The Secondary school level recorded the highest level of consumption of dietary supplements (Table 5) and this confirms that the increase knowledge and education increases of consumption and optimal use of dietary supplements among adolescents.

In study of Bailey et al., (2006) the confirmed this information, when saying that (Dietary supplement use was different among all education levels, with the highest use in those with more than a high school education $(61 \%)$ and lowest use in those with less than a high school education $(37 \%)$.

This study has indicated the prevalence of dietary supplements usage by adolescents 100 person, 54 from female and 46 from male.

The reasons for the using food supplements were for hair, skin, and nail improvements, weight gain, weight loss, bone teeth's health, increase muscle mass and anemia. The increase of knowledge is about dietary supplements about $74.5 \%$ from male and female.

\section{Recommendation}

Integrate the nutrition education courses in the different educational levels to increase the awareness about the healthful diet that can make the person abandon the consumption of dietary supplements.

It should be prevent the advertisements that shows in TV about dietary supplement especially that unauthorized from the Ministry of Health. Prevent nutritional supplements disbursed only by prescription.

Nutritional education of adolescents is highly important.

It should be performed more studies about the long-term usage and effects of supplement in adolescents.

\section{Acknowledgments}

Special thanks go to Hanoof Khaled AL-Juaid, Rehab Abdullah Zabarmawi and Huda Zuhair Khayyat for their efforts through the research.

\section{References}

Bailey RL, Dodd KW, Gahche JJ, Dwyer JT, McDowell MA, Yetley EA, Sempos CA, Burt VL, Radimer KL and Picciano MF (2006): Total folate and folic acid intake from foods and dietary supplements in the United States, 2003-2006. Am. J. Clin. Nutr. 2010; 91:231-7

Bailey RL, Fulgoni VL, Keast DR, Dwyer JT.(2011) Dietary supplement use is associated with higher intakes of minerals from food sources. Am J ClinNutr, 94: 1376-81.

Calfee R and Fadale P. (2006): Popular ergogenic drugs and supplements in young athletes. Pediatrics. 117:e577-89. 
Carvalho T (2003): Guidelines of the Brazilian Society of Sports Medicine: dietary changes, fluid replacement, food supplements and drugs: demonstration of ergogenic action and potential health risks. Rev Bras Med Esporte. 9:57-68.

Cellini M, Attipoe S, Seales P, Gray R, Ward A, Stephens M and Deuster PA. (2013): Dietary supplements: physician knowledge and adverse event reporting. Med Sci Sports Exerc.; 45(1):23-28.

Conner M, Kirk SF, Cade JE and Barrett JH (2001): Why do women use dietary supplements? The use of the theory of planned behavior to explore beliefs about their use. Social Science \& Medicine., 52(4):621-633.

Garrow JS. (1988): Obesity and related diseases. Edinburgh, Churchill Livingstone.

Houston DK, Johnson MA, Daniel TD and Poon LW (1997): Health and dietary characteristics of supplement users in an elderly population. Int J Vitam. Nutr. Res., 67(3), 183- 191.

Katarzyna Korzeniowska., Molinero $\mathrm{O}$ and Márque S (2014) Use of nutritional supplements in sports: risks, knowledge, and behavioural-related factors. Nutr Hosp; 24:128-134.

Kathy Radimer, Bernadette Bindewal, Jeffery Hughes Bethene Ervin, Christine Swanson, and Mary Frances Picciano (2004): Dietary Supplement Use by US Adults. J Epidemiol; 160:339-349.

Kim D. Dorscha and Ali Bellb (2005): Dietary supplement use in adolescents. Curr. Opin. Pediatr., 17:653-657.
Liu RH (2013): Health-promoting components of fruits and vegetables in the diet. $A d v$ Nutr.; 4(3):384S-392S.

Maughan RJ, King DS and Lea T. (2004): Dietary supplements. J Sports Sci.22:95113.

Pereira RF, Lajolo FM and Hirschbruch MD. (2003): Consumo de suplementosporalunos de academias de ginásticaem São Paulo. Rev Nutr.16:26572.

Petróczi A, Naughton DP, Mazanov J, Holloway A and Bingham J. (2007): Limited agreement exists between rationale and practice in athletes' supplement use for maintenance of health: a retrospective study. Nutr J. 6:34.

Radimer KL (2005): Methodological issues in assessing dietary supplement use in children. J Am Diet Assoc, 105 (5), 703708.

Robert, D.L. and David, C.N. (2006): Nutritional Assessment $2^{\text {nd }}$ edition. $P u b$. By McGrawhill. USA.

Scofield DE and Unruh S. (2006): Dietary supplement use among adolescent athletes in central Nebraska and their sources of information. J Strength Cond Res.20:4525.

SPSS (2008): Statistical package for social science, computer software ver.10 SPSS Company, London, UK.

Valeria Del Balzo, Valeria Vitiello, Alessia Germani, Lorenzo M. Donini, Eleonora Poggiogalle and Alessandro Pinto (2014): A Cross-Sectional Survey on Dietary Supplements Consumption among Italian Teen-Agers. DOI: 10.1371/journal.pone. 0100508 .

\section{How to cite this article:}

Reham A. Moustafa. 2018. Factors and Common Conditions Associated with Consumption of Nutritional Supplements among Adolescents in Makkah, Saudi Arabia. Int.J.Curr.Microbiol.App.Sci. 7(04): 1358-1368. doi: https://doi.org/10.20546/ijcmas.2018.704.152 